\title{
Sustainability of corporate based shallot farming business: Evidence from Malang Regency, Indonesia
}

\author{
Rita Parmawati ${ }^{1 *}$, Rizha Hardyansah ${ }^{1}$ and Aditia Rahmawati ${ }^{2}$ \\ ${ }^{1}$ Postgraduate School, Brawijaya University, Malang, Indonesia \\ 2Office for the Food Crops, Horticulture and Plantation, Malang Regency, Indonesia \\ *Correspondence email: ritaparmawati1990@gmail.com
}

\section{ARTICLE INFO}

\section{- Research Article}

\section{Article History}

Received 5 October 2020

Accepted 31 January 2021

Published 1 April 2021

\section{Keywords}

agribusiness;

multidimensional scaling;

partnership; shallot;

sustainable agriculture

JEL Classification

Q01; Q02; Q20

\begin{abstract}
Shallot is the strategic horticulture commodity and one of superior national commodities. Ministry of Agriculture initiated a pilot project for the development of a corporate based shallot farming business area in Ngantang dan Pujon Districs, Malang Regency. This research aims to analyze the sustainability of the shallot farming in Ngantang and Pujon Districts, Malang Regency. Multidimensional Scaling (MDS) RAP-Shallot's analysis with five dimensions (ecological, economic, social, institutional, and technological) was used with a total of 49 attributes. The results of the sustainability index analysis show that the institutional, technological, and social dimensions are classified as quite sustainable, but the ecological and economic dimensions are still classified as less sustainable. Some attributes that are sensitive to the sustainability of shallot farming include integrated pest and disease control, marketing access of shallots, conflicts related to farming, the role of the middleman in harvest collecting, and the use of high quality and certified bulb. To improve the sustainability of shallot farming, the supervision and management of each attribute must be carried out optimally and integrated with many stakeholders such as farmers, traders, cooperatives, and the government.
\end{abstract}

To cite this article: Parmawati, R., Hardyansah, R. \& Rahmawati, A. (2021). Sustainability of corporate based shallot farming business: Evidence from Malang Regency, Indonesia. Journal of Socioeconomics and Development, 4(1), 46-56. https://doi.org/10.31328/jsed.v4i1.1644

ISSN 2615-6075 online; ISSN 2615-6946 print (C)WG Press, 2021

\section{INTRODUCTION}

The agricultural sector significantly contributes and cannot be separated from the development of the Indonesian economy (Bashir et al., 2018). This sector also has a significant impact on reducing the unemployment rate because it can absorb $28.79 \%$ of the total workforce in Indonesia and increase foreign exchange through superior export commodities. According to BPS (2020), from 2016 to 2019 the agricultural sector on average contributed $13.4 \%$ to Indonesia's Gross Domestic Product (GDP) following trade and industry sectors. The agricultural sector consists of several sub-sectors which include food, horticultural, plantation, livestock, agricultural services, and hunting. Each of these subsectors plays a role in the economy and agricultural development in Indonesia, and the horticulture sub-sector has good prospects with high potential for commodity diversity (Waryanto et al., 2014).

Agricultural Strategy Plan of The Indonesia Ministry of Agriculture of 2014-2019 states that shallot is the strategic horticulture commodity and 
one of superior national commodities. Shallot has a high economic value and has been intensively cultivated by farmers. Also, it has an impact on regional and national economic development (Sumarni et al., 2005). The shallot production always increases every year with average national productivity of 9.93 tons/hectare or $3.55 \%$ from 2015-2019, but the production has not been able to meet the needs of shallot in Indonesia (Kustiari, 2018). It is due to the increase in the shallot consumption in Indonesia (0.529 ounces/week), considering that shallots are a type of vegetable that cannot be replaced by other commodities in term of utilization (Irawan, 2007). The high level of public consumption is comparable to market price fluctuations. It is due to a gap in the quantity and quality of shallot production, which is still seasonal and has an unsustainable pattern (Kustiari, 2018).

At the producer level, the price is more stable than that at the consumer level, which is more volatile, potentially harming farmers and consumers. Astuti and Mailena (2019) stated that the price gap from the producer and consumer occurs due to the long marketing chain and the large amount of margins received by the middlemen. Apart from the production instability and the price of shallot, another problem is farmers' cultivation pattern which only focuses on increasing production without paying attention to natural resources and the environment. Research results from Lawalata et al. (2017), Moekasan (2012), and Sulistiyono, et al. (2008) show that the productivity of shallot can decrease because of the use of pesticides and chemical fertilizers that ignores compatibility and spraying doses, the use of bulb as seeds, the use of monoculture farming systems, and climate change. These conditions encourage the farmers to understand sustainable agriculture more in order to achieve the economic and social needs by using environmentally friendly technology and community empowerment. Consequently, the natural resources and the environment can be preserved.

Malang Regency is one of the most significant contributors to shallot commodity in East Java, and in 2018 it was able to produce around $13.4 \%$ or 49,478 tons. It makes shallot a leading commodity in Malang Regency. Based on the Decree of the Ministry of Agriculture No. 46/KPTPS/SR.130/D/6/2018, Malang Regency, especially Ngantang and Pujon Districts, was used as a pilot project location for the development of a corporate based shallot farming business area. According to statistical data of Office for the Food Crops, Horticulture and Plantation of Malang Regency, Ngantang and Pujon Districts have the largest shallot production with $90 \%$ of the total district production. The data from DTPHP showed that only $35 \%$ of shallot farmers carry out balanced fertilization according to the proper dose and only $35 \%$ of farmers carry out integrated pest and disease control. Hence, it is crucial to study the sustainability of shallot farming in Malang Regency.

Previous research related to the sustainability analysis of shallot was carried out by Waryanto (2014) in Nganjuk Regency using an efficiency approach for the economic, environmental and social aspects. Research by Susilawati et al. (2019) was conducted in Brebes Regency, Central Java to see the sustainability on economic, ecological, social, institutional and technological aspects. Susilawati et al. (2019) stated that based on the results of Multidimensional Scaling (MDS) analysis, shallot farming in Brebes Regency is classified as less sustainable with the index of 46.18 . From the 45 sustainability attributes, only 17 attributes are classified as sensitive and have an effect on the sustainability of shallot farming. This result contrasts the research results by Mar'atusholikha et al. (2019) which stated that the sustainability index of garlic farming in Tegal Regency is quite sustainable with a value of 65.44. In addition, the results of this study stated that policy intervention by the central and local governments will greatly affect the sustainability of garlic farming.

However, from several previous studies, it is necessary to research the application of the government small-scale farmer corporate concept to increase farmers' trust in the sustainable agriculture concept (Dalimunthe and Kurnia, 2018). Besides, Erbaugh et al. (2019) stated that a local scale sustainability analysis is needed to facilitate monitoring and evaluation as well as measurable environmental and social objectives. In order to obtain a comprehensive assessment result of shallot farming based on farmer corporations in Malang Regency, a sustainability study was conducted based on an analysis of five dimensions, specifically ecology, economy, social, technology, and institutions.

Therefore, the objective of this research is to analyze the sustainability of shallot farming in 
Ngantang and Pujon Districts, Malang Regency. The implementation of the concept of sustainable development is expected to be able to describe the sustainability of shallot farming based on farmer corporations in the region.

\section{RESEARCH METHOD}

The research location is in Ngantang and Pujon Districts, referring to the Decree of the Ministry of Agriculture No 46/KPTPS/SR. 130/D/6/2018, where these two districts are the pilot project locations for the development of the shallot area based on the farmers corporation. In this study, the respondents were 55 farmers and eight expert respondents (head of district, official worker of local agriculture office, agricultural and environmental experts, and agricultural workers).

Primary data collection was carried out using a questionnaire distributed to farmers and experts to find out information on the sustainability attributes (ecological, economic, social, technological, and institutional). Interviews were conducted to explore data regarding the importance of strategic factors. The required secondary data were the biophysical environment conditions, the area of agricultural land, agro-climate and land condition, economic and sociocultural situation, institutional and marketing conditions, and policies.

The sustainability analysis was carried out using Multidimensional Scaling (MDS) analysis with the Rap-SHALLOT technique and five dimensions: ecological, economic, social, institution, and technological dimensions (Fauzi and Anna, 2005; Susilawati et al., 2019). The analysis consists of Monte Carlo analysis and leverage analysis to see which attributes are sensitive to other variables. The MDS analysis results can show a sustainability index in each dimension, as shown in Table 1.

Table 1. The value of Sustainability Index

\begin{tabular}{lc}
\hline Index Score & Category \\
\hline $0-24.99$ & Unsustainable \\
$25-49.99$ & Less Sustainable \\
$50-74.99$ & Quite Sustainable \\
$75-100$ & Good/Sustainable \\
\hline Source: Thamrin et al. (2007) &
\end{tabular}

The data on sustainability key factors were processed using prospective analysis. The prospective analysis is an attempt to explore future possibilities. The analysis results provide information about the key factors and strategic objectives that play a role in shallot farming according to the needs of the actors involved in the shallot farming (Bourgeois and Jesus, 2004). These key factors will be used to describe the possible future for the development of shallot farming.

\section{RESULT AND DISCUSSION}

\section{Respondent Characteristics}

Based on the results of the interview conducted to 55 farmer respondents in Ngantang and Pujon Districts, it was found that on average, the respondents in Ngantang and Pujon Districts had elementary school (SD) and junior high school (SMP) education levels. This level of education will greatly affect the ability to receive information obtained and individual awareness, especially related to steps to improve the sustainability of shallot farming in Ngantang and Pujon Districts. This is consistent with the findings of Thamrin et al. (2012) which stated that education will influence farmers in terms of information absorption and the ability to innovate in agriculture. In addition, farmers' awareness is influenced by the level of formal and informal education held by farmers, because farmers who have higher education will have broader insights regarding agricultural productivity.

Table 2. Characteristic of Respondent

\begin{tabular}{lrc}
\hline Variable & Total & Proportion \\
\hline Age & & $\%$ \\
$30-39$ years & 9 & 16 \\
$\quad 40-49$ years & 32 & 58 \\
$\quad>50$ years & 14 & 25 \\
Sex Male & 36 & 65 \\
$\quad$ Female & 19 & 35 \\
Education & & \\
$\quad$ Elementery school & 49 & 89 \\
$\quad$ Junior High Scholl & 6 & 11 \\
\hline
\end{tabular}

Farmers in Ngantang and Pujon Districts tend to plant seasonal vegetables and fruit crops such as shallots, garlic, carrots, radishes, chilies, tomatoes, eggplant, and beans. This is indicated by the area of land owned by farmers in Ngantang District which is dominated by shallot agricultural land. Meanwhile, in Pujon District, it is still dominated by carrot farming, which is followed by petai and shallot agricultural 
land. Because of this, Ngantang and Pujon Districts, according to The Decree of the Ministry of Agriculture No. 46/KPTPS/SR. 130/D/6/2018, are used as pilot project location for the development of the corporate based shallot farming business area.

Forty-four percent of respondents live within a 400-600 m distance from the land, and 68 percent of the land is possessed by 68 percent of interviewees having an area of 0.5-29 ha. They dominate the domestic distance, affecting the production and productivity of farmers.

\section{Sustainability of Farming Business}

Multidimensional Scaling (MDS) is divided into five dimensions and several attributes that consist of ecological dimension, economic dimension, social dimension, technology dimension, and institutional dimension. The attributes in each dimension were obtained from the previous analysis and literature study. In this research, there are total of 49 attributes. It is divided in ecological dimensions (10 attributes), economic dimensions (10 attributes), social dimensions (10 attributes), institutional dimensions (10 attributes), and technological dimensions (9 attributes). Each attribute has a power to increase and decrease the sustainability value. The MDS analysis using Rap-Shallot shows the sustainability index for each dimension in Figure 1.

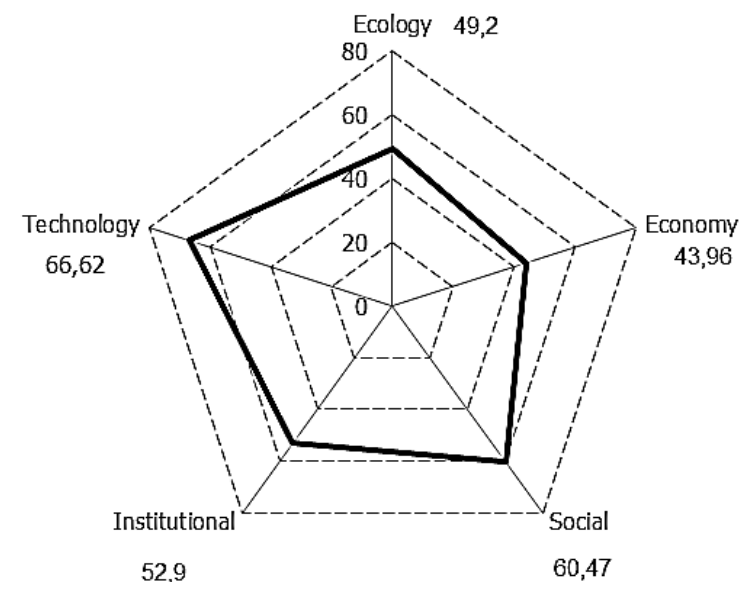

Figure 1. Sustainability index of corporate based shallot farming business

The sustainability index above shows that the technology, institutional, and social dimensions were quite sustainable with their respective values, namely $66.62 ; 52.90 ; 60.47$. It can be seen that in order to increase the sustainability of shallot farming in Malang Regency, the three dimensions (technology, institutions, and social dimensions) need to be improved by carrying out several innovations including agro-industrial development, technological innovation, giving special incentives to young farmers, developing modern agriculture, training and empowering young farmers, and introducing agricultural industry development and agricultural innovation to the younger generation from an early age (Susilawati, 2016). Meanwhile, the ecological and economic dimensions were classified as less sustainable with values of 49.20 and 43.96 respectively. Based on the average of these values, shallot farming in Malang Regency is classified as quite sustainable. The sustainability of these dimensions is influenced by several attributes in it. It is necessary to manage and improve several attributes that are considered sensitive to sustainability.

\section{Ecology dimension}

Sustainability index of ecological dimensions has the value of 49.20 , which is categorized as less sustainable. It needs many improvements to achieve sustainability, especially in sensitive attributes. The attributes that affect corporate-based shallot farming's sustainability on ecological dimension can be seen from the leverage analysis (Table 3 ).

Table 3. Leverage Value of Ecological Attributes

\begin{tabular}{lc}
\hline Attributes & $\begin{array}{c}\text { Root Mean } \\
\text { Square }\end{array}$ \\
\hline Erosion conservation & 2.43 \\
Concurrent plants & 3.55 \\
Organic additives & 5.83 \\
Utilization of agricultural waste & 5.83 \\
Agrochemical management of fertilizer use & 6.29 \\
Integrated pest management & 8.96 \\
Disease intensity & 6.10 \\
Pest intensity & 4.64 \\
Land ownership & 3.24 \\
Land resource management & 2.17 \\
\hline
\end{tabular}

The ecological dimension consists of 10 attributes that impact the sustainability of corporate based shallot farming business. The results show that integrated pest and disease management (IPM) (Leverage $=8.96$ ) were the most sensitive attributes to the sustainability of shallot farming. The results of the interview show that shallot farmers only focused on crop productivity and ignored the environmental impacts. The use of pesticides was still considered 
the most accessible and cheapest step to increase agricultural yields. However, on the one hand, pesticides' impact is hazardous for both human health and the surrounding environment. Thus, Integrated Pest and Disease Management (IPM) is needed. The application of IPM serves as a method to control pests by reducing or eliminating chemical pesticides; it uses a holistic approach between traditional habits and modern technology (Stenberq, 2017; Dara, 2019).

According to Popp et al. (2012), the use of pesticides that is not well regulated in developing countries can cause chemical pesticides to be left behind and locked in the soil. Implementing IPM aims to address all economic, environmental, and social aspects and provide safe and affordable food for consumers and benefits for producers and sellers while maintaining environmental health to achieve environmentally sound and sustainable development (Dara, 2019; Moekasan, 2012). Socialization and education related to IPM to farmers are essential, especially regarding the benefits obtained and benefits in a sustainable manner. It is inseparable from the role and cooperation of the agriculture agency, agricultural extension agents, academics, farmer groups, and the surrounding community (Fanqohoi et al., 2018; Prasetyo \& Hariani, 2018).

\section{Economic dimension}

It is shown that the value of sustainability index of economic dimensions was 43.96, categorized as less sustainable. Hence, it needs many improvements to achieve sustainability, especially in sensitive attributes. The attributes that affect corporate-based shallot farming's sustainability on economic dimension can be seen from the leverage analysis results (Table 4).

Table 4. Leverage Value of Economic Attributes

\begin{tabular}{lc}
\hline Attributes & $\begin{array}{c}\text { Root Mean } \\
\text { Square }\end{array}$ \\
\hline Market opportunity & 3.22 \\
Shallot market reach & 2.96 \\
Access to shallots market & 7.56 \\
Acquisition of farmers' business capital & 5.32 \\
Compulsory cooperative savings & 6.31 \\
Shallots price fluctuation & 6.75 \\
Farming income & 5.44 \\
Biological control costs & 3.36 \\
Labor costs & 2.57 \\
\hline
\end{tabular}

There is 9 economic attributes that impact the sustainability of corporate based shallot farming business in the Malang Regency. Attributes of the access to shallot marketing (Leverage $=7.65$ ) was classified as sensitive attributes to the sustainability of shallot farming in Malang Regency. Marketing access is an external factor that affects the agribusiness competence of farmers. If the area has a difficult marketing access, the farmers will be less interested in running the farm, which is in line with research by Andriani et al. (2017). Marketing is a collaborative process of social and administrative, such as exchanging products, services, and values with other people (Al Jaafreh, 2017). Market access to an agricultural product like shallot must be improved by cooperating with government and private agencies (local and regional).

The partnership program is essential in sustainability, especially in the attribute of market access (Puspitaningrum \& Gayatri, 2019). Action that can be done to make access is public-private partnership, which is a collaboration between the local government and the private sector utilizing various resources, knowledge, and risks to be able to streamline products and increase the distribution of products and services (Hartwich and Tola, 2007). The functions of public-private partnership include reducing production costs and business risks in each market chain, improving the quality of the products and using technology, and increasing the capacity of human resources involved in each process carried out and increasing product competitiveness marketing accessibility. Therefore, public-private partnership will increase the benefits for both parties who are working together, as well as significantly increase (farmers') income, finance (working capital), and knowledge transfer (Pasaribu, 2015).

\section{Social dimension}

The value of sustainability index of social dimensions was 60.47 , that is categorized as quite sustainable. But to achieve more sustainability, it needs many especially in sensitive attributes. The attributes that affect corporate-based shallot farming's sustainability on Social dimension can be seen from the leverage analysis results (Table 5).

The social dimension consists of 10 attributes that impact the sustainability of corporate based shallot farming business in the Malang Regency. The attribute that has a high sensitivity value towards sustainability is conflicts related to farming (Leverage $=6.33$ ). Conflict is a problem that has existed in society for a long time. The forms of the conflict vary 
according to the root of problem, such as the conflict over land tenure, which has occurred since the colonial era to this day. Conflicts that often occur in society are social conflicts, in which there is a dispute between two or more groups that lasts for a particular time and has a broad impact, resulting in insecurity and disrupting national stability (Law Number 7 of 2012; Sauni, 2016).

Table 5. Leverage Value of Social Attributes

\begin{tabular}{lc}
\hline Attributes & $\begin{array}{c}\text { Root Mean } \\
\text { Square }\end{array}$ \\
\hline Education & 2.81 \\
Other business alternatives & 3.25 \\
Conflict frequency & 3.99 \\
Activity in extension & 6.01 \\
Activeness in cooperatives & 4.31 \\
Conflicts related to farming enterprises & 6.33 \\
Duration of becoming farmer & 6.06 \\
Time allocation in farming & 3.91 \\
Motivation to become a farmer & 4.00 \\
Farming business management pattern & 3.70 \\
\hline
\end{tabular}

The sustainability index from the social dimension is classified as quite sustainable. However, increasing or maintaining this sustainability level requires serious attention toward the farming conflict's attributes. Conflicts within a farmer group can be caused by the culture and values that exist in the community, and this conflict will hinder the empowerment of the group from becoming better and more advanced. Steps to take are harmonizing perceptions within the group and creating solidarity to accelerate technology adaptation in conservation to achieve sustainability (Nuryanti and Swastika, 2011). Collaboration and partnerships among farmer groups, government, and agricultural extension agents (public-private partnership) also play an essential role in preventing conflict because optimal collaboration can create effective policies in dealing with farming problems. One such example is the implementation of production cost-based insurance, where the government provides a premium subsidy of $80 \%$ of the total premium during the planting season. This insurance model can protect farming and provide incentives for farmers (Pasaribu, 2015).

\section{Institutional dimension}

The value of sustainability index of institutional dimensions was 52.90, categorized as quite sustainable. However, to achieve more sustainability, many sensitive attributes are needed. The attributes that affect corporate-based shallot farming's sustainability on Institutional dimension can be seen from the leverage analysis results (Table 6).

Table 6. Leverage Value of Institutional Attributes

\begin{tabular}{lc}
\hline Attributes & $\begin{array}{c}\text { Root Mean } \\
\text { Square }\end{array}$ \\
\hline $\begin{array}{l}\text { Access to product processing } \\
\text { institutions/groups }\end{array}$ & 2.41 \\
$\begin{array}{l}\text { The existence of business financing institutions } \\
\text { Whether or not there is assistance from the } \\
\text { government/private sector related to }\end{array}$ & 2.02 \\
$\begin{array}{l}\text { cultivation } \\
\text { The existence of agricultural prodi providers }\end{array}$ & 3.45 \\
$\begin{array}{l}\text { The role of intermediary traders in collecting } \\
\text { harvest }\end{array}$ & 3.62 \\
$\begin{array}{l}\text { The existence of management in solving } \\
\text { member problems }\end{array}$ & 4.91 \\
$\begin{array}{l}\text { The role of the existence of corporations in } \\
\text { farming enterprises }\end{array}$ & 4.52 \\
$\begin{array}{l}\text { The role of extension officers in assisting } \\
\text { farmers }\end{array}$ & 3.85 \\
$\begin{array}{l}\text { Frequency of managerial counseling for farmer } \\
\text { corporations }\end{array}$ & 4.1 \\
Frequency of shallot cultivation extension & 3.7 \\
\hline
\end{tabular}

The institutional dimension consists of 10 attributes that impact the sustainability of corporate based shallot farming business in the Malang Regency. There are two key attributes that need to be considered for this institutional dimension's sustainability. These attributes are the middlemen's role in collecting harvests (Leverage $=4.91$ ) and the corporation's existence in farming (Leverage $=4.52$ ). These two attributes must be enhanced in order to encourage other attributes to develop and achieve sustainability. Between the two attributes above, the middlemen's role in collecting the harvest is the main attribute that must be considered. Middlemen are an essential aspect of the process of trading and distributing commodities. Based on its activities, middlemen are divided into those who carry out the transactions and those who only provide intermediary services. However, middlemen's key role is as the bridge between producers and consumers so that the produced commodities can be sold and consumers get their needs. Some middlemen also participate in the process of determining commodity prices. This action can cause unbalanced prices and decreased consumer demand. The role limitations of the middlemen should be evaluated. Beside that, the corporation's role in farming needs to be increased because it is related to how farmers manage costs or make loans in terms of the farming business. 
Even with technological advances and corporations that deal with distribution route problems, farmers still depend on these middlemen. Farmers need training and ease of information regarding the middlemen distribution channel, although it is possible that intermediary traders can become venture capital providers with an agreed agreement. Therefore, middlemen's functions and duties must be clarified to accelerate shallot farming's turnover of funds. Research results from Charina et al. (2012) showed that middlemen can be categorized as semi-social businesses by establishing partnerships with farmers due to the ever-increasing consumer demand for a commodity.

Apart from middlemen's role, a corporation's existence is a crucial matter to note. Agricultural corporations can be an attempt to increase the scale of farmer's business because they can provide support services in the form of banking access, agricultural technology application services, and government policy extension services (Prasetyo \& Hariani, 2018; Jhon Wardie \& Sintha, 2018). If farmers still use the old, individualistic mindset, this will be an obstacle to shallot farming's sustainability. Farmers' corporation can be a forum for cooperation between farmers, a place to share knowledge and experiences related to agriculture, as an absorber of labor, and, most importantly, a driver of the village economy (Nugroho et al., 2018).

\section{Technology dimension}

The sustainability index of technology dimensions was 66.62 and was categorized as quite sustainable. To achieve more sustainability, many sensitive attributes are needed. The attributes that affect corporate-based shallot farming's sustainability on technology dimension can be seen from the leverage analysis results (Table 7).

The technological dimension consists of 9 attributes that impact the sustainability of corporate based shallot farming business in the Malang Regency. Some attributes are considered as sensitive factors for shallot farming's sustainability. These attributes are the use of quality and certified bulb (Leverage $=6.03$ ) and IPM technology (Leverage = 5.75). The two attributes are closely related in influencing the sustainable status of the technological dimension. Its implementation in shallot farming needs to be more considered and appropriately managed to increase this dimension's sustainability index in the future. Bulbs are a vital factor in farming production, and a good hatchery system will support increased production. Budhi and Aminah's (2010) research showed that poor quality bulbs can hinder production and reduce farmers' productivity. Besides, shallot production's competitiveness is partly due to the high cost of farming for bulbs, labor, and pesticides, where they use $90 \%$ of the funds received by farmers (Aldila et al., 2017), leading to such impact as farmers' small profit.

Table 7. Leverage Value of Technology Attributes

\begin{tabular}{lc}
\hline Attributes & $\begin{array}{c}\text { Root } \\
\text { Mean } \\
\text { Square }\end{array}$ \\
\hline Application of agricultural waste treatment & 4.55 \\
technology & \\
Application of harvest according to standards & 3.54 \\
Application of ipm technology & 5.75 \\
Application of disease pest control & 5.13 \\
Application of pesticide doses & 4.52 \\
Application of doses of fertilizer & 4.79 \\
Organic fertilizer during planting & 4.32 \\
Use of quality and certified seeds & 6.03 \\
How to cultivate land & 5.24 \\
\hline
\end{tabular}

In general, most farmers still use planting material from the previous shallot harvest, buy from other farmers, or use imported bulbs (Basuki, 2010). Some imported bulbs also use consumption tubers to grow into a new bulb even though tuber bulbs have several disadvantages, e.g. bulbs cannot be stored for a long time, the transportation cost is expensive, and sometimes the tubers carry infectious plant diseases (Rosliani et al., 2016). To reduce this risk, farmers can use TSS (True Bulb Shallot) technology to produce quality bulbs. TSS is a botanical bulb produced by old shallot flowers and reprocessed into a bulb. This bulb also has some advantages, i.e. it can be stored for a long time, it does not require a large storage area, it has high productivity, and it is disease- and virus-resistant (Rosliani et al., 2016). Apart from using quality bulb, the implementation of the IPM program is highly recommended. Excessive use of pesticides is not considered efficient for shallot productivity (Nurjati et al., 2018). Although pesticides are a preventive measure, if the doses are not used correctly, the pests will become resistant. Failure to control pests can cause decreasing production and farmers' income. IPM is highly recommended to be used as it increases the sustainability of the technological dimension; it can also impact the ecological dimension. 


\section{Research Implication}

The results of research related to the sustainability of shallot farming in Malang Regency have implications for the formulation of policies in determining the right strategy to improve the sustainability of shallot farming which will involve various parties: farmers, cooperatives, traders, farm management, and government. In addition, this strategy must later be emphasized to control HPT of shallots, overcome price fluctuations, and facilitate access in the marketing of shallots.

Pests can reduce the productivity of shallot agricultural areas. Based on Sutardi and Porwoningsih's (2018) research results, there are several pests in shallot plants, including Diptera, Thysanoptera, Hymenoptera, Hemiptera, Coleoptera, Lepidoptera, and Acarina. The method often used by farmers to overcome the threat from these pests is to use chemical pesticides. It was found that pesticides contain organochlorines, organophosphates, carbamates, and pyrethroidscontaminates, which pollute the ecosystem and accumulate in a fixed food chain, as well as endanger the health of other living things (Blasco et al., 2003). To overcome this problem, farmers need to handle pests in an environmentally friendly manner by implementing Integrated Pest and Disease Management (IPM). The IPM application is based on modern technology and the community's local wisdom (Stenberg, 2017; Dara, 2019). As for the benefits of implementing IPM, Dinakaran et al. (2013) showed that compared to the use of chemical pesticides, the application of IPM in Tamil Nadu can reduce production costs up to $2.60 \%$, increase tuber production by $19.28 \%$, and increase profits up to $23.89 \%$. The role of agricultural extension agents and the existence of facilities and infrastructure are essential in socializing and applying the concept of the IPM to farmers. It is because the different mindsets among farmers have an impact on their ability to invest. Thus, socializing and implementing the IPM do not involve just one party, but they require synergy from the local governments, local communities, and academics.

Shallots are categorized as commodities that cannot be replaced, so the demand tends to increase every time. Shallots are also a commodity that is not too affected by price fluctuations because it has an elasticity value classified as inelastic (-0.68)
(Soedjana, 2013). However, the high demand is not followed by sufficient production in Indonesia, so there are frequent price fluctuations. Those fluctuations can be due to the increase in planting costs, weather conditions, reduced stocks, transportation costs, or imported shallots. The main responsible party for these problems is the government, either local or national.

The government must be able to make appropriate policies and take appropriate actions when the price fluctuation of this shallot occurs. They must also ensure that the stock of shallots is still sufficient for market demand. Also, the government needs to initiate the policies to facilitate transportation for the access to public facilities or infrastructure, as well as respond to middlemen's existence by building marketing facilities from producers to consumers and creating areas for shallot production centers in areas considered to have adequate topography support. Central and local government's policies and actions in terms of production, distribution, and marketing side are their primary responsibility. In its implementation, the government must also consider farmers' opinions because they are the very individuals who understand better the real field conditions. It is necessary to have a forum that can bridge the thoughts of farmers and the government to produce policies that are right on target and more optimal.

The industrial revolution 4.0 era is one of the driving forces to providing easy access for farmers or producers to market their goods. It cannot be separated from agricultural products such as shallots. Shallot marketing currently still has a long market chain, with many middlemen involved, whose existence can harm the price of the shallot commodity. The role of the middlemen itself is still dominant in many markets and agricultural locations. Limited access to technology and information is the reason farmers are forced to sell their products to the middlemen. According to the farmers, this step is efficient because they feel confident that their goods will be sold and paid accordingly. However, in fact, the payments received are often far below the selling price on the market.

There are at least two possible steps to provide direct access to farmers, namely (i) creating a digital platform with a collaboration among government, academics, and farmers to facilitate marketing, and (ii) implementing a public-private partnership 
program. Creating a digital platform requires continuous collaboration of agricultural extension agents, government, academics, and farmers (Fangohoi et al., 2018). Due to gaps in educational background, the implementation of this digital platform may be hampered. However, if the collaboration is sustainable, the digital platform marketing method's results will increase farmer's economy. Also, the implementation of public-private partnership will increase the benefits received by all involved parties, as well as significantly increase (farmers') income, finance (working capital), and knowledge transfer (Pasaribu, 2015). This kind of cooperation is expected to support food selfsufficiency and improve the welfare of farmers.

\section{CONCLUSION AND SUGGESTION}

The sustainability of corporate-based shallot farming business in the Malang Regency is classified as quite sustainable. It is shown by the sustainability index on technology, institutional, and social dimensions with their respective index, namely 66.62; 52.90; and 60.47. However, two dimensions are still categorized as less sustainable from the five dimensions: the ecological and economic dimensions with the values of 49.20 and 43.96, respectively.

The research finds several sensitive attributes that significantly determine the sustainability of shallot farming. The attributes are integrated pest and disease control, access to marketed shallots, conflicts related to farming, the role of middlemen in collecting harvests, and the use of quality and certified bulb. They need to be appropriately managed in order to increase the sustainability of each of the existing dimensions.

To improve the sustainability of shallot farming in the Malang Regency, all stakeholders (farmers, cooperatives, traders, administrators, and the government) must be involved. The step that can be taken is formulating policies that produce sustainable agricultural management strategies and positively impact producers and consumers. The policy strategy needs to pay more attention to factors related to disease intensity in shallots in Malang Regency, price fluctuations, and access to shallot marketing.

\section{REFERENCES}

Al Jaafreh, O. (2017). The role of food marketing in sustainable agriculture (case study of Hungary).
In Proceedings of the 6th International Conference on Economic Sciences, 1-13. https://doi.org/10.22587/aejsa.2020.14.1.1

Aldila, H.F., Fariyanti, A., \& Tinaprilla, N. (2017). Daya saing bawang merah di wilayah sentra produksi di Indonesia. J. Manaj. Agribis, 14(1), 43-53. https://doi.org/10.17358/jma.14.1.43

Andriani, R., Kusumo, B., \& Charina, A. (2017). Analisis keberlanjutan praktik pertanian sayuran organik di Kecamatan Parongpong Kabupaten Bandung Barat. Jurnal Agribisnis Terpadu, 10(2), 129-140. https://doi.org/10.33512/jat.v10i2.5064

Astuti, E.P., \& Mailena, L. (2019). Strategi pengembangan usaha pertanian cabai berbasis korporasi pada Gapoktan Mujagi Kecamatan Pacet Kabupaten Cianjur. Buletin Inovasi Pertanian Spesifik Lokasi, 5(1), 71-83. https://doi.org/10.25157/ma.v1i1.31.s16

Bashir, A., Susetyo, D., Suhel., \& Azwardi. (2018). The relationship between economic growth, human capital, and agriculture sector: empirical evidence from Indonesia. International Journal of Food and Agricultural Economics, 6(4), 35-52. https://doi.org/10.22004/ag.econ.283873

Basuki, R.S. (2010). Sistem pengadaan dan distribusi benih bawang merah pada tingkat petani di Kabupaten Brebes. Jurnal Holtikultura, 20(2), 187-195.

http://doi.org/10.21082/jhort.v20n2.2010.p\%25p

Blasco, C., M. Fernandez., A. Pena., C. Lino., M.I. Silveira., G. Font., \& Y. Pico. (2003). Assessment of pesticide residues in honeysamples from Portugal and Spain. J Agric Food Chem, 51(27), https://doi.org/8132-8. 10.1021/jf034870m.

Bourgeois, R., \& Jesus, F. (2004). Participatory Prospective Analysis: Exploring and Anticipating Challenges with Stakeholders, (1437-2016118895), 112. Monograph Number 46. UNESCAPCAPSA. https://doi.org/10.22004/ag.econ.32731

BPS (Badan Pusat Statistik). (2020). Produk Domestik Bruto Indonesia Triwulanan 2016-2020. Jakarta: Badan Pusat Statistik Republik Indonesia.

Budhi, G.S., \& Aminah, M. (2010). Swasembada kedelai: antara harapan dan kenyataan. Forum Penelitian Agroekonomi, 28(1), 55-68. http://doi.org/10.21082/fae.v28n1.2010.55-68

Charina, A., Mukti, G.W., \& Andriani, R. (2012). Kajian bisnis sosial pedagang perantara dalam upaya pengembangan hortikultura di Jawa Barat. Jurnal Sosial Ekonomi Pertanian, 1(1), 33-51. https://doi.org/10.26418/j.sea.v1i1.2118 
Dalimunthe, I.M., \& Kurnia, G. (2018). Prospek penerapan sistem corporate farming (Studi Kasus di Koperasi Pertanian Gerbang Emas). Jurnal Agrisep, 16(1), 11-22. https://doi.org/10.31186/agrisep.17.1.11-22

Dara, S.K. (2019). The new integrated pest management paradigm for the modern age. Journal of Integrated Pest Management, 10(1), 19. https://doi.org/10.1093/jipm/pmz010

Dinakaran, D., Gajendran, G., Mohankumar, S., Karthikeyan, G., Thiruvudainambi, S., Jonathan, E. I., Samiyappan, R., Pfeiffer, D.G., Rajotte, E.G., Norton, G.W., Miller, S., \& Muniappan, R. (2013). Evaluation of integrated pest and disease management module for shallots in Tamil Nadu, India: A farmer's participatory approach. Journal of Integrated Pest Management, 4(2), 1-9. https://doi.org/10.1603/IPM12019

Erbaugh, J, Rosina, B., Guillermo, C., Gustavo, A.B. da Fonseca., \& Steffen, C.B.H. (2019). Towards sustainable agriculture in the topics. World Development, 121(2019), 158-162. https://doi.org/10.1016/j.worlddev.2019.05.002

Fangohoi, L., Sugiyanto, S., Sukesi, K., \& Cahyono, E. D. (2018). Establish the perception of agricultural extension workers through cyber extension as the media information. Journal of Socioeconomics and Development, 1(1), 32-37. https://doi.org/10.31328/jsed.v1i1.530

Fauzi, A. \& Anna, S. (2005). Pemodelan Sumber Daya Perikanan dan Kelautan. Jakarta: PT. Gramedia Pustaka Utama. https://books.google. co.id/books?id=QwQj3ZjPKiMC

Hartwich, F., \& Tola, J. (2007). Public-private partnerships for agricultural innovation: Concepts and experiences from 124 cases in Latin America. International Journal of Agricultural Resources, Governance and Ecology, 6(2), 240-255. https://doi.org/10.1504/ijarge.2007.012706

Irawan, B. (2007). Fluktuasi harga, transmisi harga, dan marjin pemasaran sayuran dan buah. Analisis Kebijakan Pertanian, 5(4), 358-373. http://doi.org/10.21082/akp.v5n4.2007.358-373

Kustiari, R. (2018). Perilaku harga dan integrasi pasar bawang merah di Indonesia. Jurnal Agro Ekonomi, 35(2), 77-87. http://doi.org/10.21082/jae.v35n2.2017.77-87

Lawalata, M., Dwijono, H.D., \& Slamet, H. (2017). Risiko usahatani bawang merah di Kabupaten Bantul. Jurnal Agribisnis Sumatera Utara, 10(2), 56-73. https://doi.org/10.31289/agrica.v10i2.924
Mar'atusholikha, V., Widiatmaka., \& Firmansyah, I. (2019). Sustainability of garlic cultivation at Tegal Regency, Central Java Province. In IOP Conference Series: Earth and Environmental Science, 399, 012027. https://doi.org/10.1088/1755-1315/399/1/012027

Moekasan, T.K., 2012. Penerapan ambang pengendalian organisme pengganggu tumbuhan pada budidaya bawang merah dalam upaya mengurangi penggunaan pestisida. Jurnal Hortikultura, 22(1), 47-56. http://doi.org/10.21082/jhort.v22n1.2012.p47-56

Nugroho, F.M., Satmoko, S., \& Karno. (2018). Peran kelompok tani terhadap usahatani padi di Kecamatan Sale Kabupaten Rembang. J. Agro Complex, 2(2), 109-119. https://doi.org/10.14710/joac.2.2.109-119

Nurjati, E., Fahmi, I., \& Jahroh,S. (2018). Analisis efisiensi produksi bawang merah di kabupaten pati dengan fungsi produksi frontier stokastik Cobb-Douglass. Jurnal Agro Ekonomi, 36(1), 5569. http://doi.org/10.21082/jae.v36n1.2018.5569

Nuryanti, S., \& Swastika D.K.S. (2011). Peran kelompok tani dalam penerapan teknologi pertanian. Forum Penelitian Agroekonomi, 29(2), 115-128.

http://doi.org/10.21082/fae.v29n2.2011.115-128

Pasaribu, S.M. (2015). Program kemitraan dalam sistem pertanian terpadu. Analisis Kebijakan Pertanian, 13(1), 39-54. http://doi.org/10.21082/akp.v13n1.2015.39-54

Popp, J., Peto, K., \& Nagy, J. (2012). Pesticide productivity and food security: A review. Agronomy for Sustainable Development, 33(1), 243-255. https://doi.org/10.1007/s13593-0120105-x

Prasetyo, H., \& Hariani, L. (2018). Performance evaluation of the extension worker and the development strategy of organic agriculture extension in Batu City. Journal of Socioeconomics and Development, 1(2), 79-87. https://doi.org/10.31328/jsed.v1i2.594

Puspitaningrum, D. A., \& Gayatri, S. (2019). Farm partnership between farmers and the company in production and marketing of vegetables commodity. Journal of Socioeconomics and Development, 2(1), 45-53. https://doi.org/10.31328/jsed.v2i1.975

Rosliani, R., Hidayat, I.M., Sulastrini, I., \& Hilman, Y. (2016). Dissemination of technology for shallot (Allium ascalonicum L.) bulb production using 
true shallot bulb (TSS) in Indonesia. Acta Hortic. 1143, 345-352. https://doi.org/10.17660/ ActaHortic.2016.1143.49

Sauni, H. (2016). Konflik penguasaan tanah perkebunan. University of Bengkulu Law Journal, 1(1), https://doi.org/10.33369/ubelaj.v1i1.1327

Soedjana, T.D. (2013). Partisipasi konsumsi sebagai alat ukur status ketahanan pangan daging. Wartazoa, 23(4), 166-175. Retrieved from http://jurnal.Ippm.unsoed.ac.id/ojs/index.php/Pro siding/article/viewFile/1243/1094

Stenberg, J. (2017). A conceptual framework for integrated pest management. Trends in Plant Science, 22(9), 759-769. https://doi.org/10.1016/j.tplants.2017.06.010

Sulistiyono,L., Tarumingkeng, R.C., Sanim, B., \& Dadang. (2008). Pengetahuan sikap dan tindakan petani bawang merah dalam penggunaan pestisida (Studi Kasus di Kabupaten Nganjuk, Provinsi Jawa Timur). Agroland, 15(1): 12-17. Retrieved from http://jurnal.untad.ac.id/jurnal/ index.php/AGROLAND/article/viewFile/37/31

Sumarni, N., E. Sumiati., \& Suwandi. (2005). Pengaruh kerapatan tanaman dan aplikasi zat pengatur tumbuh terhadap produksi umbi bibit bawang merah asal biji kultivar Bima. Jurnal Hortikultura, 15(3), 208-214. http://doi.org/10.21082/jhort.v15n3.2005.p\%25p

Susilawati, S.H. (2016). Fenomena penuaan petani dan berkurangnya tenaga kerja muda serta implikasinya bagi kebijakan pembangunan pertanian. Forum Penelitian Agro Ekonomi, 34(1), 35-55. Retrieved from http://124.81.126.59/handle/123456789/7554.

Susilawati, D.M., Maarif, M.S., Widiatmaka., \& Lubis, I. (2019). Appraisal of shallot farming sustainability in Brebes Regency, Central Java
Province, Indonesia. Bulgarian Journal of Agricultural Science, 25(5), 872-882. Retrieved from https://www.agrojournal.org/25/05-06.html

Sutardi., \& Porwoningsih, H. (2018). Environementfriendly cultivation of shallot on sandy land as specified location in Yogyakarta. Jurnal Sumberdaya Hayati, 4(1), 1-6. https://doi.org/10.29244/jsdh.4.1.\%25p

Thamrin, M., S. Herma., \& F. Hanafi. (2012). Pengaruh faktor sosial ekonomi terhadap pendapatan petani pinang. Agrium, 17(2), 134144. https://doi.org/10.30596/agrium.v17i2.277

Thamrin., Sutjahjo, S.H., Herison, C., \& Sabihan, S. (2007). Analisis keberlanjutan wilayah perbatasan Kalimantan Barat-Malaysia untuk pengembangan kawasan agropolitan (Studi kasus kecamatan dekat perbatasan Kabupaten Bengkayang). Jurnal Agro Ekonomi, 25(2), 102-124. http://doi.org/10.21082/jae.v25n2.2007.103-124

Wardie, Jhon, \& Sintha, T. Y. E. (2018). The sustainability level of the rice farming in the peatland at The Kapuas Regency, Central Kalimantan. Journal of Socioeconomics and Development, 1(1), 38-42. https://doi.org/10.31328/jsed.v1i1.531

Waryanto, B. (2014). Analisis efisiensi teknis, efisiensi ekonomis dan daya saing pada usahatanani bawang merah di Kabupaten Nganjuk Jawa Timur: Suatu Pendekatan Ekonometrik dan PAM. Infromatika Pertanian, 23(2), 147-158. http://doi.org/10.21082/ip.v23n2.2014.p147-158

Waryanto, B., Chozin, M.A., Dadang., Putri, E.I.K. (2014). Environmental efficiency analysis of shallot farming: a stochastic frontier translog regression approach. Journal of Biology, Agriculture and Healthcare, 4(19), 87-100. http://doi.org/10.21082/ip.v24n2.2015.p233-244. 